\title{
Isolation and Optimization of Endophytic Bacteria from Roots of Karst Area Ecosystems Producing Protease Enzymes
}

\author{
Halifah Pagarra ${ }^{1}$, HARtati $^{2}$, Alimuddin Ali ${ }^{3}$, Pince SAlempa ${ }^{4}$ And Muharram Passita ${ }^{5}$ \\ ${ }^{1}$ Department of Biology, Universitas Negeri Makassar, Makassar, Indonesia. \\ ${ }^{2}$ Department of Biology, Universitas Negeri Makassar, Makassar, Indonesia. \\ ${ }^{3}$ Department of Biology, Universitas Negeri Makassar, Makassar, Indonesia. \\ ${ }^{4}$ Department of Chemistry, Universitas Negeri Makassar, Makassar, Indonesia. \\ ${ }^{5}$ Department of Chemistry, Universitas Negeri Makassar, Makassar, Indonesia. \\ 1halifah.pagarra@unm.ac.id, ${ }^{2}$ hartati@unm.ac.id, ${ }^{3}$ muddin_69@unm.ac.id, ${ }^{4}$ pince.salempa@unm.ac.id, \\ ${ }^{5}$ muharram.pasma@yahoo.co.id
}

\begin{abstract}
.
This study aims to determine the activity of the protease enzyme from bacterial A isolates isolated from Karst plant roots in various incubation time variations. Bacterial isolates used were isolates of bacteria A, proteolytic thermophilic bacteria isolated from Karst Ecosystem in Pangkajene Regency, South Sulawesi Province. Testing of protease activity was carried out using the Lowry method. The highest crude protein content of all treatments was obtained at 48 hours incubation time for Bacterial Isolates A $(8.329 \mathrm{mg} / \mathrm{ml})$. The results showed that Bacterial Isolate A showed an optimal production time at 48 hours with an enzyme activity of 0.423 Units $/ \mathrm{ml}$. While the exponential phase of bacterial growth on 48-hour incubation act with a maximum optical density of 1.444. It can be concluded that Bacterial Isolate A is a proteolytic bacterial characterized by the formation of a clear zone around the bacterial colony on the SMA. The production of protease enzymes obtained through RSM (CCD) method is optimum at $0.485 \mathrm{U} / \mathrm{ml}$ at glucose concentration of $0.60 \%$, yeast extract $1.50 \%$ and skim milk $3.00 \%$. SDS-PAGE analysis showed that the protease enzyme from Isolate A was 15, 20 and $37 \mathrm{kDa}$.
\end{abstract}

Keywords. Crude Protein, Proteenzyme Activity and Bacterial Isolates A.

Received: 24 March 2020

Accepted: 05 April 2020

DOI: 10.36872/LEPI/V51I2/301110 


\section{INTRODUCTION}

Ogino et al., 2008, explained that Protease represented one of the three largest industrial enzyme groups and found applications. According to Mahajan and Shumatt (2010), the known source of protease enzymes comes from animals, microbes and plants. Plants are the largest source of protease enzymes (43.85\%) followed by bacteria (18.09\%), fungi $(15.08 \%)$, animals $(11.15 \%)$, algae $(7.42 \%)$ and viruses $(4.41 \%)$. The role of microorganisms in enzyme production is very important because it has a high ability in production, low costs and vulnerability to genetic manipulation. Endophytic microorganisms occupy relatively unexplored locations in isolating microorganisms so that they can represent new sources in obtaining more enzymes with different potential (Carrim et al., 2006).

The purpose of this study was the isolation of endophytic microorganisms from karst plant roots and the production of protease enzymes by isolates. More specifically, it is to determine the activity of the protease enzyme from bacterial A isolates isolated from Karst plant roots in various incubation time variations. Bacterial isolates used were isolates of bacteria A, proteolytic thermophilic bacteria isolated from Karst Ecosystem in Pangkajene Regency, South Sulawesi Province. Testing of protease activity was carried out using the Lowry method.

\section{EXPERIMENT}

\section{Plant root Sampling}

Plant root sampling was carried out at Karst Ecosystem, Pangkep Regency. Plant root samples in each ecosystem were taken using machetes, plant root samples were then put into plastic samples. Then the sample is put into a cool box and taken to the laboratory. Microorganism selection was carried out on endophytic bacterial isolates from plant roots originating from karst ecosystems in Pangkep Regency. The medium used is skim milk agar, $10 \%$ liquid skim milk (which is sterilized at $110^{\circ} \mathrm{C}$ for 10 minutes) and GYS media containing $0.3 \%$ glucose, $1 \%$ yeast extract, $2 \%$ skim milk (Astutiati, 2010) in erlenmeyer $250 \mathrm{~mL}$ containing $50 \mathrm{~mL}$ medium.

\section{Endophytic Bacteria Selection}

Selection was carried out in a skim milk agar medium on a Petri dish containing $15 \mathrm{~mL}$ of solid medium. Endophytic bacteria aged 24 hours were inoculated on skim milk medium to use sterile toothpicks and then incubated for 72 hours. The clear zone formed is measured using the method of Sukara (1989).

\section{Coagulation Test on Liquid Milk Skim Medium}

A $24 \%$ endophytic bacterial suspension of $2 \%$ (bacterial culture in a tube dissolved with $2.5 \mathrm{~mL}$ of sterile distilled water) was inoculated into $5 \mathrm{~mL}$ of $10 \%$ liquid skim milk medium in a test tube and incubated for 7 days. 
Observations were made on changes in medium (coagulation, medium color and $\mathrm{pH}$ ) (modification of Saran, et al., 2007).

\section{Fermentation Process}

The suspension of the best bacterial isolate was inoculated into a $250 \mathrm{~mL}$ Erlenmeyer containing $50 \mathrm{~mL}$ of medium as much as $3 \%$. Subsequently incubated at room temperature for 72 hours. Fermented samples were centrifuged at $10,000 \mathrm{rpm}$ for 10 minutes.

Analysis

The filtrate from the fermented sample was measured for protein content using the method of Hanson and Philips (1981). Analysis of protease enzyme activity using the Arima et al. (1968) which was modified.

\section{Protease Enzyme Activity Test}

$0.5 \%$ casein was dissolved in $0.02 \mathrm{M}$ buffer of Potassium Phosphate while heated on the bath. After dissolving, $1.25 \mathrm{~mL}$ of substrate is taken and then put into a tube reaction and heated at a temperature of $35^{\circ} \mathrm{C}$ for 30 minutes in a water bath. Furthermore, $0.25 \mathrm{ul}$ of the enzyme was added and incubated at $35^{\circ} \mathrm{C}$ for 10 minutes (if necessary the enzyme was diluted first) then removed and added $1.25 \mathrm{~mL}$ of TCA $(0.44 \mathrm{M})$ and then shaken using vortex, then centrifuged at $10,000 \mathrm{rpm}$ for 10 minutes. The filtrate was taken as much as $0.5 \mathrm{~mL}$ and then added $1.25 \mathrm{~mL}$ of $\mathrm{Na}_{2} \mathrm{CO}_{3}(0.55 \mathrm{M})$ and $0.5 \mathrm{~mL}$ of Folin, then divorted and then incubated at $35^{\circ} \mathrm{C}$ for 20 minutes. Last measured by using a spectrophotometer at a wavelength of $660 \mathrm{~nm}$ (Arima et al., 1968).

\section{RESUlTS AND DiscuSSION}

Endophytic microorganisms (fungi and bacteria) are microorganisms that inhabit the inside of plants at least in the vital cycle period, and are found in tissues such as leaves, branches, and roots. These endophytic microorganisms do not cause damage to the host, which distinguishes them from phytopathogenic microorganisms. A protease (also called a peptidase or proteinase) is any enzyme that carries out proteolysis, that is, initiating protein catabolism by hydrolysis of peptide bonds that connect amino acids together in the polypeptide chains that make up proteins. They have diverse applications in various industries such as biscuit making, the brewing industry (Jain et al, 2012).

Proteolytic activity tests were carried out on isolate A (gram postive) using SMA. A positive test was shown by the presence of a clear zone around the bacterial colony on the SMA media. Qualitative test results indicate that isolate $\mathrm{A}$ is a proteolytic bacterium because it is able to produce protease enzymes which are characterized by the formation of clear zones around bacterial colonies. Isolate A which are proven to have proteolytic activity are then used as a starter in the production process of protease enzymes.

The proteolytic activity of isolate A on the SMA media is shown in Figure 1. Protein contained in the selective medium of SMA acts as an inducer for the protease enzyme. The clear zone produced is the result of 
hydrolysis of protein substrate contained in SMA media by protease enzymes produced by bacterial isolates. The SMA media contains peptone and skim milk as the main carbon source for the needs of bacterial metabolism.

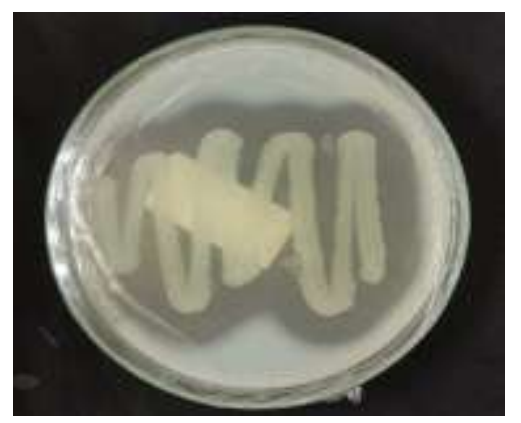

Figure 1. Qualitative test results of proteolytic activity of Bacterial Isolates A on SMA

Determination of crude protein content is done quantitatively. Figure 2, show the results of testing crude protein levels in each treatment. The highest crude protein content of all treatments was obtained at 48 hours incubation time for Bacterial Isolates A $(8.329 \mathrm{mg} / \mathrm{ml})$.

Determination of optimal production time is done at the time of production 0, 24, 48, 72 and 96 hours by Bacterial Isolate A. The results showed that Bacterial Isolate A showed an optimal production time at 48 hours with an activity of $0.423 \mathrm{Unit} / \mathrm{ml}$.

After achieving optimal production time, Bacterial Isolate A decreased enzyme activity. The increase in enzyme activity at the beginning of production time is thought to be caused by the availability of large amounts of nutrients needed by bacterial cells to carry out cell metabolism. At the end of the enzyme production time, there is a decrease in proteolytic activity which can occur due to the reduced amount of the substrate which will inhibit the formation of the enzyme substrate complex and changes in the structure of the enzyme which will cause a decrease in catalytic rate. Due to changes in enzyme structure, the active side of the enzyme changes in shape so that it cannot be used properly in binding the substrate (Yuniati, 2015). Another possibility is that the bacteria's need for amino acid nutrition.

\section{Growth Patterns of Bacillus Subtilis}

The growth curve of Bacterial Isolates A can be determined by measuring the turbidity of the media used for growth on the medium with a certain time interval to determine the ability of these bacteria to multiply cells. Turbidity measurements using a spectrophotometer without counting the actual number of microbes, because the large molecules contained in the media are also counted when exposed to light at the time of calculation. According to Susanti (2003), turbidity occurs because bacterial cells grow, develop, multiply, and secrete enzymes to culture media. Bacterial growth curve acts to determine the time at which microbes enter the final logarithmic phase or the beginning of the stationary phase, this is done to get the maximum enzyme.

Optical Density of droplets containing culture of growing bacteria, during the incubation period from 0 hours to 144 hours. Figure 4. It has been shown that the lag phase can be ignored. During the log phase at 24 to 48 
hours the incubation period a strong increase from 0.171 to 1,444 was observed. After 48 hours, the turbidity of the medium containing the bacteria decreased sharply and this decrease also continued in the death phase. Records of changes in OD from a droplet containing bacterial culture are shown in Figure 4. It appears that optical density increases from the lag phase through the $\log$ phase to $\mathrm{OD}=1,444$, and then slightly decreases in the death phase.

\section{Optimization of Protease Enzyme using Experimental Design and Statistical Analysis}

Which involves three different factors. The experiment was carried out randomly. CCD contains a total of 20 experimental experiments that involve replication of central points. The dependent variable chosen for this study was the activity of the Protease enzyme (U/ ml). The selected independent variables are glucose level (\%), $\mathrm{X}_{1}$; yeast extract (\%) $\mathrm{X}_{2}$ and skim milk (\%), X3. After the experiment, the second order polynomial equation (1) shown below is used to illustrate the effect of variables in terms of linear, quadratic and cross product terms. In $\mathrm{CCD}$, the range and level of variables investigated in this study are as given in Table 1.

\section{Table 1. Code and actual values of the factors in central composite design}

\begin{tabular}{|l|l|l|l|l|l|l|}
\hline Var. & Parameter & \multicolumn{5}{l|}{ Level } \\
\cline { 3 - 8 } & & $-\alpha$ & -1 & 0 & +1 & $+\alpha$ \\
\hline Glucose & $\%$ & 0.06 & 0.20 & 0.40 & 0.60 & 0.74 \\
\hline Yeast Extract & $\%$ & 0.16 & 0.50 & 0.100 & 0.15 & 1.84 \\
\hline Skim Milk & $\%$ & 0.32 & 1.00 & 2.00 & 3.00 & 3.68 \\
\hline
\end{tabular}

Where, Y represents the activity of the protease enzyme $(\mathrm{U} / \mathrm{ml}), \mathrm{b}_{0}$ is intercept term, $\mathrm{b}_{1}, \mathrm{~b}_{2}, \mathrm{~b}_{3}$ linear coefficients, $b_{11}, b_{22}, b_{33}$ squared coefficients and $b_{11}, b_{13}, b_{23}$ are interaction coefficients. Combinations of factors (such as X1X2) represent an interaction between the individual factors in that term. Then the response is a function of the levels of factors. The response surface graphs indicate the effect of variables individually and in combination and determine their optimum levels for maximal protease production. To validate these predictions, flask cultivation using the completely optimized medium composition was carried out thrice. While $\mathrm{X}_{1}, \mathrm{X}_{2}$, and $\mathrm{X}_{3}$ respectively represent glucose, yeast extract and skim milk.

\section{Optimization of Protease Enzyme Activity}

Protease enzyme optimization results analyzed by analysis of variance. glucose, yeast extract, skim milk and interactions between glucose and yeast extract, glucose and skim milk and extract yeast and skim milk in a manner significantly affect the production of enzymes protease as shown in Table 2. Based on ANOVA results, the best regression model (Table 3) with a regression value $\left(R^{2}\right)$ of 0.95 was determined by using Equation 2. $X_{1}$, $\mathrm{X}_{2}$ and $\mathrm{X}_{3}$ each shows glucose, yeast extract and skim milk while $\mathrm{Y}$ is protease enzyme activity. Regression coefficient and the significance of the Response model Surface Quadratic can be seen in Table 3. 


$$
Y=0.094+0.081+0.017+0.030+0.082+0.095+0.065+0.039(2)
$$

Table 2. Regression analysis (ANOVA) for Protease Enzyme activity using 2 - level factorial design

\begin{tabular}{|l|l|c|c|c|c|}
\hline Source & Sum of Square & DF & Mean Square & F Value & $\begin{array}{l}\text { Prob. } \\
>\mathrm{F}\end{array}$ \\
\hline Model & 0.33 & 9 & 0.036 & $69.46^{\mathrm{a}}$ & $<0.0001^{\mathrm{b}}$ \\
\hline $\mathrm{X}_{1}$ & 0.089 & 9 & 0.036 & 169.70 & $<0.0001$ \\
\hline $\mathrm{X}_{2}$ & 3.929 & 1 & 0.089 & 7.53 & 0.0207 \\
\hline $\mathrm{X}_{3}$ & 0.012 & 1 & 3.929 & 23.10 & 0.0007 \\
\hline $\mathrm{X}^{2}$ & 0.098 & 1 & 0.012 & 187.30 & $<0.0001$ \\
\hline $\mathrm{X}_{2}{ }^{2}$ & 7.588 & 1 & 0.098 & 1.45 & 0.2557 \\
\hline $\mathrm{X}_{3}{ }^{2}$ & 2.392 & 1 & 2.392 & 0.46 & 0.5138 \\
\hline $\mathrm{X}_{1} \mathrm{X}_{2}$ & 0.073 & 1 & 0.073 & 13.76 & $<0.0001$ \\
\hline $\mathrm{X}_{1} \mathrm{X}_{3}$ & 0.034 & 1 & 0.034 & 64.76 & $<0.0001$ \\
\hline $\mathrm{X}_{2} \mathrm{X}_{3}$ & 0.012 & 1 & 0.012 & 23.01 & 0.0007 \\
\hline Residual & 5.220 & 10.522 & 5.22 & - & - \\
\hline Lack of Fit & 3.978 & 5.7 & 7.957 & 3.2 & $0.1136^{\mathrm{c}}$ \\
\hline Pure Error & 1.242 & 5.2 & 2.484 & - & - \\
\hline Cor Total & 0.33 & 19 & - & - & - \\
\hline
\end{tabular}

${ }^{a} F$-Value is significant.

${ }^{\mathrm{b}}$ Model is significant, with $\mathrm{p}>\mathrm{F}$ lower than 0.05 .

${ }^{c}$ model is fit due to not significant $F$-value.

Standard deviation is 0.023

Based on ANOVA results, the best regression model (Table 3) with Regression values $\left(\mathrm{R}^{2}\right)$ of 0.984 were determined using Equation 2. $\mathrm{X}_{1}, \mathrm{X}_{2}$ and $\mathrm{X}_{3}$ respectively showed yeast extract and skim milk while $\mathrm{Y}$ is the activity of the protease enzyme (Equation 2). Regression coefficient and significance of the Response model Surface Quadratic can be seen in Table 3.

Table 3. Regression coefficient and significance of the Quadratic Response Surface model

\begin{tabular}{|l|l|l|l|l|l|}
\hline Factor & $\begin{array}{l}\text { Coefficient } \\
\text { Estimate }\end{array}$ & $\mathrm{DF}$ & $\begin{array}{l}\text { Standard } \\
\text { Error }\end{array}$ & $95 \% \mathrm{Cl}$ & $95 \% \mathrm{Cl}$ \\
\cline { 4 - 6 } & & & & Low & High \\
\hline Intercept & 0.094 & 1 & 9.319 & 0.073 & 0.11 \\
\hline $\mathrm{X}_{1}$-Glucose & 0.081 & 1 & 6.183 & 0.067 & 0.094 \\
\hline $\mathrm{X}_{2}$-Yeast Extract & 0.017 & 1 & 6.183 & 3.185 & 0.031 \\
\hline $\mathrm{X}_{3}$-Skim Milk & 0.030 & 1 & 6.183 & 0.016 & 0.043 \\
\hline $\mathrm{X}_{1}{ }^{2}$ & 0.082 & 1 & 6.019 & 0.069 & 0.096 \\
\hline $\mathrm{X}_{1} \mathrm{X}_{2}$ & 0.095 & 1 & $8 / 078$ & 0.078 & 0.11 \\
\hline $\mathrm{X}_{1} \mathrm{X}_{3}$ & 0.065 & 1 & 8.078 & 0.047 & 0.083 \\
\hline $\mathrm{X}_{2} \mathrm{X}_{3}$ & 0.039 & 1 & 8.078 & 0.021 & 0.057 \\
\hline
\end{tabular}


The graph of the experimental results is visualized in the form of three dimensions and plot contour of response surface that is shows the relationship between two factors interacting with enzymes protease Glucose and yeast extract concentrations and their interactions have a significant effect on the activity of the protease enzymes produced as shown in Figure 2. Glucose and skim milk concentrations and their interactions have a significant effect on the activity of the protease enzymes produced as shown in Figure 3. Similarly, the concentration of yeast extract and skim milk and the interactions shown in Figure 4 also have a significant effect on the activity of the protease enzymes produced.

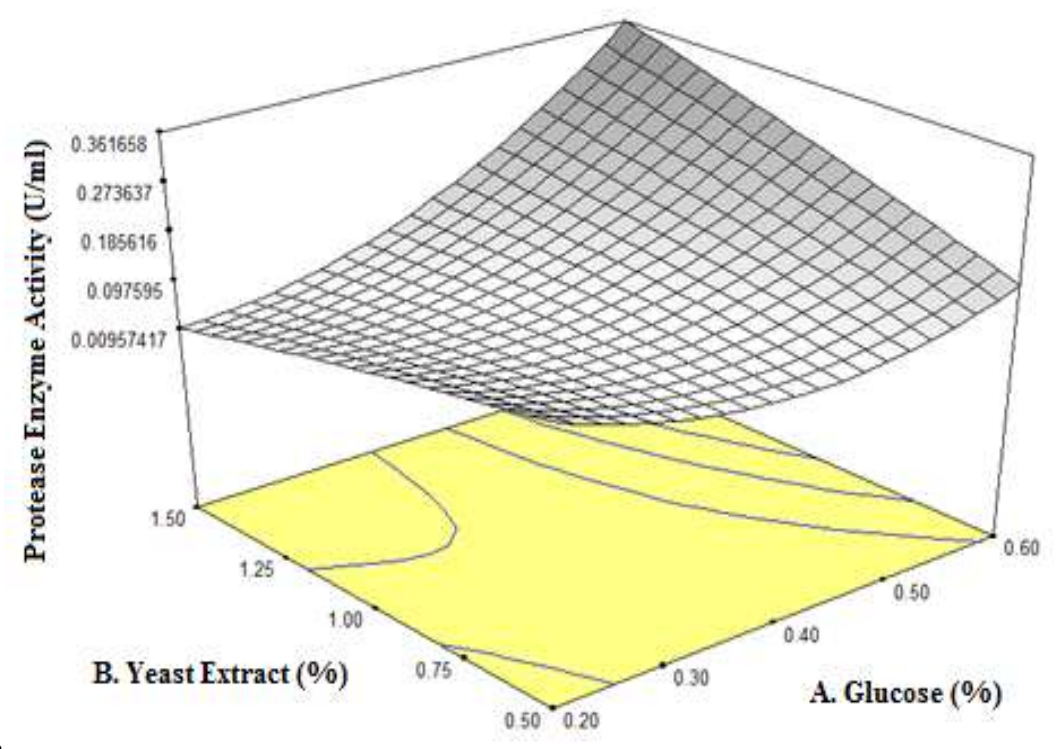

Figure 2. Response Surface Plot of protease enzyme activity: effect of glucose and yeast extract.

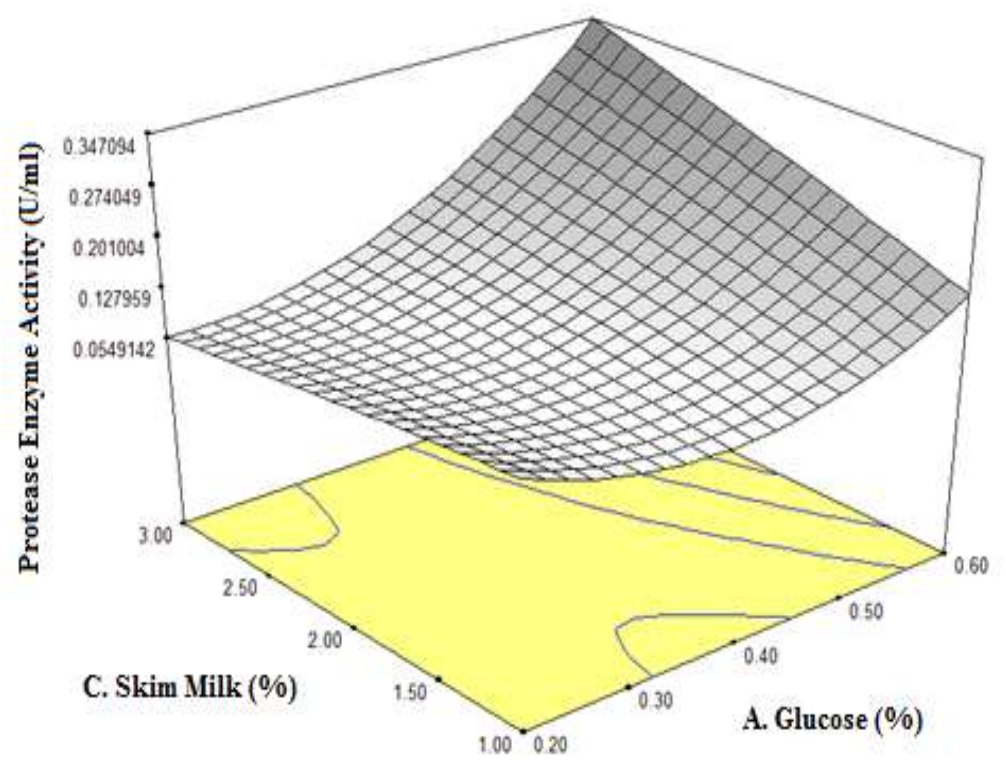

Figure 3. Response Surface Plot of protease enzyme activity: effect of glucose and skim milk 


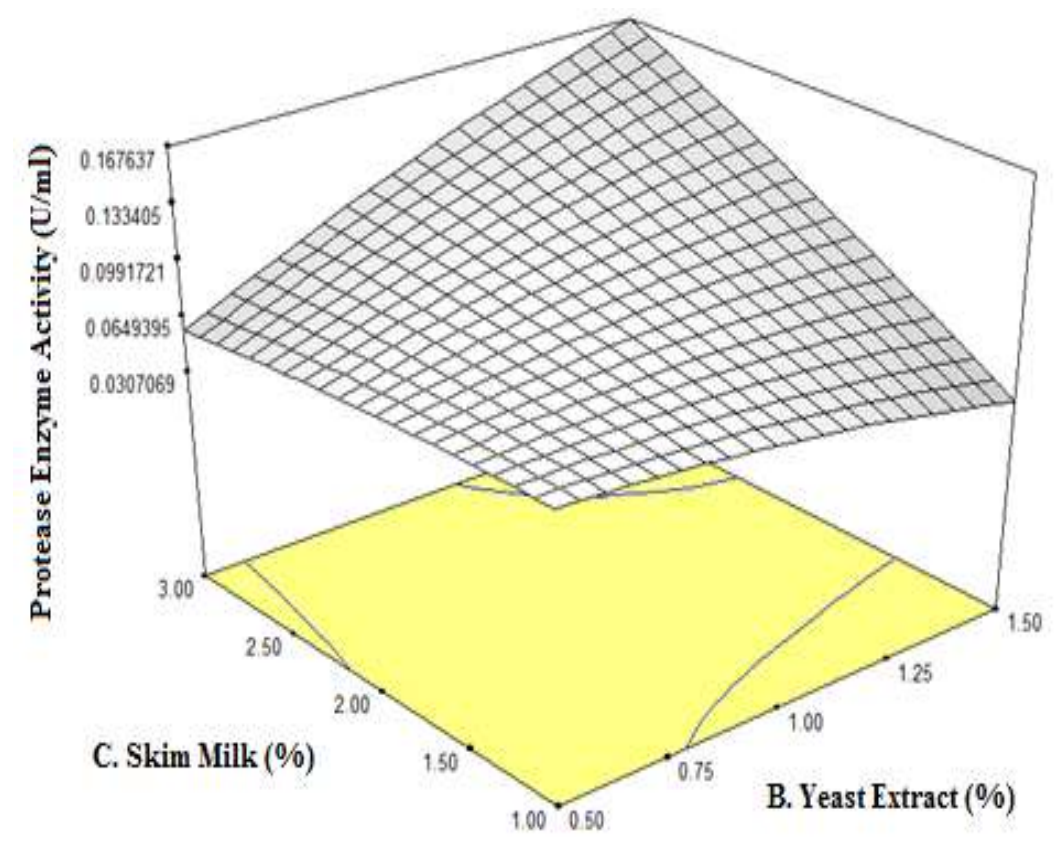

Figure 4. Response Surface Plot of protease enzyme activity: effect of yeast extract and Determination of Molecular Weight skim milk

Determination of protease enzyme molecular weight was done using SDS-PAGE and confirmed with protein markers. Based on the calculation results, 4 protein bands were obtained from isolate A which had molecular weights of 15, 20, 50, 75 and $150 \mathrm{kD} \mathrm{kDa}$ (Figure 5). Of the four protein bands obtained, it is not known whether all of them have protease activity. Therefore protein markers are used to confirm the active band that has activity.

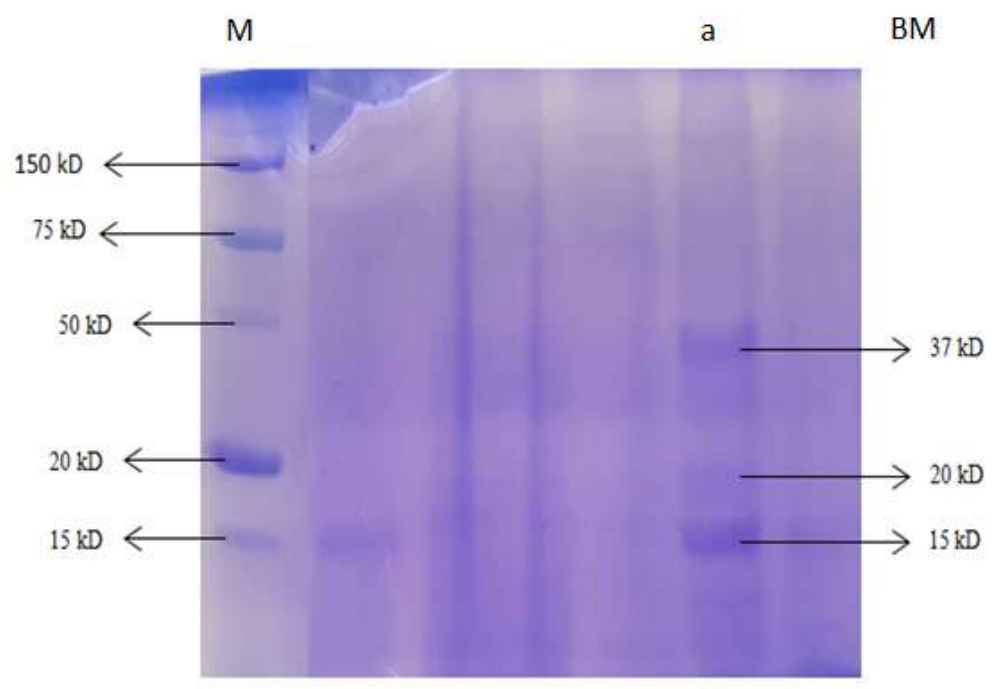

Figure 5. Electrophoresis of protease enzyme isolates A. (M) protein markers, (a) dialysis protease enzymes, (BM) Molecular Weight of protease enzymes 
Based on the results of SDS-Page with marer protein as standard (Figure 5) it can be seen that there are only 3 protein bands that show protease activity namely at molecular weights of $15 \mathrm{kDa}, 20 \mathrm{kDa}$ and $37 \mathrm{kDa}$. The presence of protease activity on the zimogram is indicated by the formation of a clear zone. The area that forms a clear zone is a casein substrate area that has been degraded by the protease enzyme. According to Mehzard et al. (2005), Coomassie Brilliant Blue G250 (CBBG) dyes will bind to proteins containing amino acid residues with aromatic side chains (tyrosine) forming a blue complex. The SDS-polyacrylamide gel was copolymerized with casein to form a clear zone due to degradation by the protease enzyme.

\section{CONCLUSION}

Based on the results of research that has been done, it can be concluded that Bacterial Isolate A is a proteolytic bacterial characterized by the formation of a clear zone around the bacterial colony on the SMA. Isolate A bacteria had optimum production time of crude protein at $8,329 \mathrm{mg} / \mathrm{ml}$ at 48 hours incubation time and optimum enzyme activity at 0.423 Units $/ \mathrm{mL}$ at 48 hours incubation time. While the exponential phase of bacterial growth on 48-hour incubation act with a maximum optical density of 1.444 .

\section{REFERENCES}

[1] Arima K, Yu J, Iwasaki S, Tamura G (1968). Milk-clotting enzim from microorganism: Purification and crystallization of Mucor rennin from Mucor pusillus var. Lindt. Applied Microbiology 16(11): 1747-1733.

[2] Carrim AJI, Barbosa EC, Vieira JDG (2006). Enzymatic activity of endophytic bacterial isolates of Jacaranda decurrens Cham. (Carobinha-do-campo). Brazilian Archives of Biology and Technology 49(3): 353-359.

[3] Jain P, Aggarwal V, Sharma A, Pundir RK (2012). Isolation, production and partial purification of protease from an endophytic Acremonium sp. J. Agric. Tech, 8: 1979-1989.

[4] Mahajan RT, Dan Shamnkant BB (2010). Biological Aspects of Proteolytic Enzymes: A Review. India J. Pharm. Research 3(9): 2048-2068.

[5] Mehzard J, Desrosier C, Lauzon, Robitaille G, Zhao X, Lacasse P (2005). Zymogram Technique for Proteolitic Assay. J Dairy Sci., 88: 211-222.

[6] Ogino H, Otsubo T, Ishikawa H (2008). Screening, purification, and Characterization of a leather-degrading protease. Biochemical Engineering Journal 38: 234-240.

[7] Saran S, Isar J, Saxena RK (2007). A modified method for the detection of microbial proteases on agar plates using tannic acid. J. Boichem. Bioph. Meth., 70: 697-699.

[8] Sukara E, Doelle HW (1989). A one-step process for the production of single-cell protein and amyloglucosidase. Appl Microbiol Biotechnol 30: 135-140.

[9] Susanti EVH (2003). Isolasi dan Karakterisasi Protease dari Bacillus subtilis 1012M15. Jurnal Biodiversitas 4(1): $12-17$.

[10] Yuniati R, Titania T, Nugroho, Fifi P (2015). Uji Aktivitas Enzim Protease dari isolat Bacillus sp. Galur Lokal Riau. Journal FMIPA 1(12): 116-122. 